\title{
Genome-wide Gene Expression Profiles of Prostate Cancer Cells and Identification of Molecular Targets for Prostate Cancer Treatment and Biomarker.
}

\author{
東京大学医科学研究所ヒトゲノム解析センター \\ 中川 英刀, 中村 祐輔
}

前立腺癌は我が国に扔いて近年急速に増加傾向にあり、今後欧米同様に癌死の主要因となることが推測される。し かし再燃、ホルモン抵抗性に至った前立腺癌に対する有効な治療法は現段階ではなく、新規治療法の開発は急務で ある。また、早期前立腺癌や前癌病変に対するアプローチとしては、予防という観点からも欧米では議論されてお り、前立腺癌の発生、進展に関する遺伝子レベルでの病態解明は最も関心の寄せられる研究領域である。

前立腺癌は組織学的に非常に heterogeneousであり、癌細胞の他に、前癌病変と考えられる PIN、正常腺細胞、そ して多くの間質細胞が前立腺癌組織を占めている。この heterogeneity を克服し、これら腫瘍細胞の正確な遺伝子 発現プロファイルを作製すべく、我々はこれまでホルモン抵抗性前立腺癌を含む前立腺癌組織より、Laser Microbeam Microdissection 法を用いて、前立腺癌細胞、PIN および正常前立腺腺上皮細胞を純化し、ゲノムワイドの cDNA マイクロアレイによって、それらの遺伝子発現プロファイルの作製を行ってきた。この正確かつ大量の遺伝

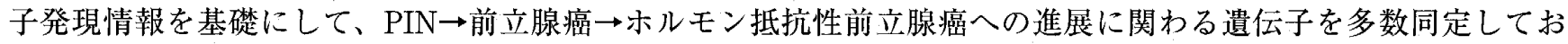
り、前立腺癌の発生・進展といった病態の解明への糸口となるような知見を紹介する。さらには、前立腺癌細胞㧍 よび正常各臟器の遺伝子発現情報に基づいて、前立腺癌細胞で特異的に発現立進を認める遺伝子も多数同定し、そ れらを前立腺癌の分子標的または biomarkerの候補として、創薬や新規治療法の開発の可能性を念頭におきつつ、 その機能解析を行ってきているので、その一部を紹介する。

S7-4

\section{膀胱内圧測定用超小型テレメトリー発信機の開発}

鹿児島大学工学部情報工学科

竹内 康人

蓄尿や排尿の動態、また日常生活中の膀胱の挙動などは未だよく分らない面が多いが、従来の知見の 1 つの制約と して、観測系の侵襲性と言うか、妨害性というか、すなわち測定する事で自然な現象を大きく妨げている点がある。 また従来の観測・測定系の設計思想では本質的に観測・測定し得ない事象もある。本研究に扔いては従来の経尿道 的に“長い物”を入れた状態で外から測ると言う思想を一切廃し、膀胱内に独立した装置として圧センサと無線伝送 装置を一体化した物を置いて、無拘束、無妨害の状態で日常生活中の蓄尿、排尿の動態を観測する事を目指してい る。我々の開発中の膀胱内圧測定用超小型テレメトリー発信機のプロトタイプ装置は本稿執筆の時点では in vitro test の段階であるが、直径約 $7 \mathrm{~mm}$ 長さ約 $20 \mathrm{~mm}$ の表面平滑な外套カプセルに閉鎖ベローズ式の圧変位変換機構执 よび変位を発振周波数に変換する可動磁芯型可変インダクタンス式の高周波発振回路、1 次電池などを一括して収 容している。発振出力は体外の結合コイルで拾われ、得られた高周波信号は受信機に、また続く周波数解析装置に 引き渡される。カプセルの見掛の比重を調整する事で膀胱内では浮力を得て常時“一番上”に留まる様に考慮され る。このようなカプセルを経尿道的に膀胱内に送り达み、また自然排尿とともに“出て来る”事を狙っているが、実 際にはもう少し小さい (例えば $6 \mathrm{~mm} \phi \times 10 \mathrm{~mm}$ とか) 必要がある事が伺われる。本研究による体胿内への送入と回 収を目的とした内圧測定用超小型テレメトリー発信機は膀胱内圧測定用の外に設計如何では無数の用途 (例えば子 宮内圧とか) が考えられ、埋め込み式も、カテーテル式や穿刺針式もともに適用が困難な場面に扮いて新しい医用 計測の世界が開けるものと期待される。発表においてはその後の進渉も含め報告したい。 